\title{
Lessons learned from COVID-19 on potentially pathogenic soil microorganisms
}

\author{
Haifeng Qian ${ }^{1, *}$, Qi Zhang ${ }^{1}$, Tao Lu1 ${ }^{1}$, W.J.G.M. Peijnenburg ${ }^{2,3}$, Josep Penuelas ${ }^{4,5}$, Yong-Guan Zhu ${ }^{6,7,8}$ \\ 1 College of Environment, Zhejiang University of Technology, Hangzhou 310032, China \\ 2 Institute of Environmental Sciences (CML), Leiden University, 2300 RA Leiden, The Netherlands \\ 3 National Institute of Public Health and the Environment (RIVM), Center for Safety of Substances and Products, P.O. Box 1, Bilthoven, \\ The Netherlands \\ 4 CSIC, Global Ecology Unit CREAF-CSIC-UAB, Bellaterra, 08193 Barcelona, Catalonia, Spain \\ 5 CREAF, Cerdanyola del Vallès, 08193 Barcelona, Catalonia, Spain \\ 6 Key Laboratory of Urban Environment and Health, Institute of Urban Environment, Chinese Academy of Sciences, Xiamen 361021, China \\ 7 University of the Chinese Academy of Sciences, Beijing 100049, China \\ 8 State Key Laboratory of Urban and Regional Ecology, Research Center for Eco-environmental Sciences, Chinese Academy of Sciences, \\ Beijing 100085, China
}

(C) Higher Education Press 2020

\section{Pathogenic soil microbes: an issue of international concern}

The current Coronavirus Disease 2019 (COVID-19) pandemic, and previous $\mathrm{H} 1 \mathrm{~N} 1$ and SARS epidemics, were not completely accidental. The transfer of viruses and other microorganisms among humans, animals, plants, and environmental compartments (e.g., soil or water) is a common natural phenomenon (Zhu et al., 2017; Zhu et al., 2020), but the frequencies of disease epidemics and pandemics have been increasing $(\mathrm{Wu}$, 2017; Zhang and Gao, 2018). Agricultural intensification is postulated to be one of the most pervasive factors exacerbating these problems in the 20-first century (Foley et al., 2011). Current agricultural practices disturb the microbial world, accelerate the evolution of pathogen resistance and virulence, and together with host-range expansions and host jumps contribute to severe outbreaks of disease (Vannier et al., 2019). Environments such as the soil (Williamson et al., 2017), deep sea (Danovaro et al., 2008), and glaciers (Bellas et al., 2015) harbor many largely unknown pathogenic viruses and microorganisms. Meanwhile, global warming may facilitate the release of ancient pathogenic microorganisms and advance the population dynamics of viruses (Frenken et al., 2020; Labbé et al., 2020; Zhong et al., 2020), which can infect humans health through extreme weather or through the

Received August 8, 2020; Revised September 24, 2020; Accepted October 6, 2020

* Corresponding author

E-mail address: hfqian@zjut.edu.cn (H.F. Qian) carriage of plants and animals. The soil pathogenic microbes, indigenous or exogenous pathogenic microbes in the soil that have the potential to cause disease to humans, are typically in balance with other microbes due to subtle interactions and soil properties, such as Salmonella, of which longevity in the soil depends on the interaction with indigenous microorganisms (Locatelli et al., 2013; Schierstaedt et al., 2020). However, this balance can be disrupted by the use of pesticides and fertilizers and by other types of industrial pollution, which may indirectly increase the competitive niche of pathogenic microbes and cause blooms, which increase the likelihood of outbreaks of disease in humans (Fig. 1). Numerous soil pathogens can directly cause human infections and present a pandemic potential (Table 1) (Steffan et al., 2020). For instance, Bacillus anthracis is found in soils as endospores and can be inhaled by humans under extreme weather conditions, causing humans and animals to suffer from anthrax. Increased attention and priority should therefore be given to the interactions between agricultural compounds and soil pathogenic microbes, and the trends in opportunistic disease outbreaks among humans should be monitored. These actions will greatly benefit the prediction and management of the continuously increasing number of emerging infectious diseases.

\section{Dynamic of pathogenic soil microorganisms}

Soils are one of the most dense and diverse microbial habitats on our planet. One gram of soil has been estimated to contain 


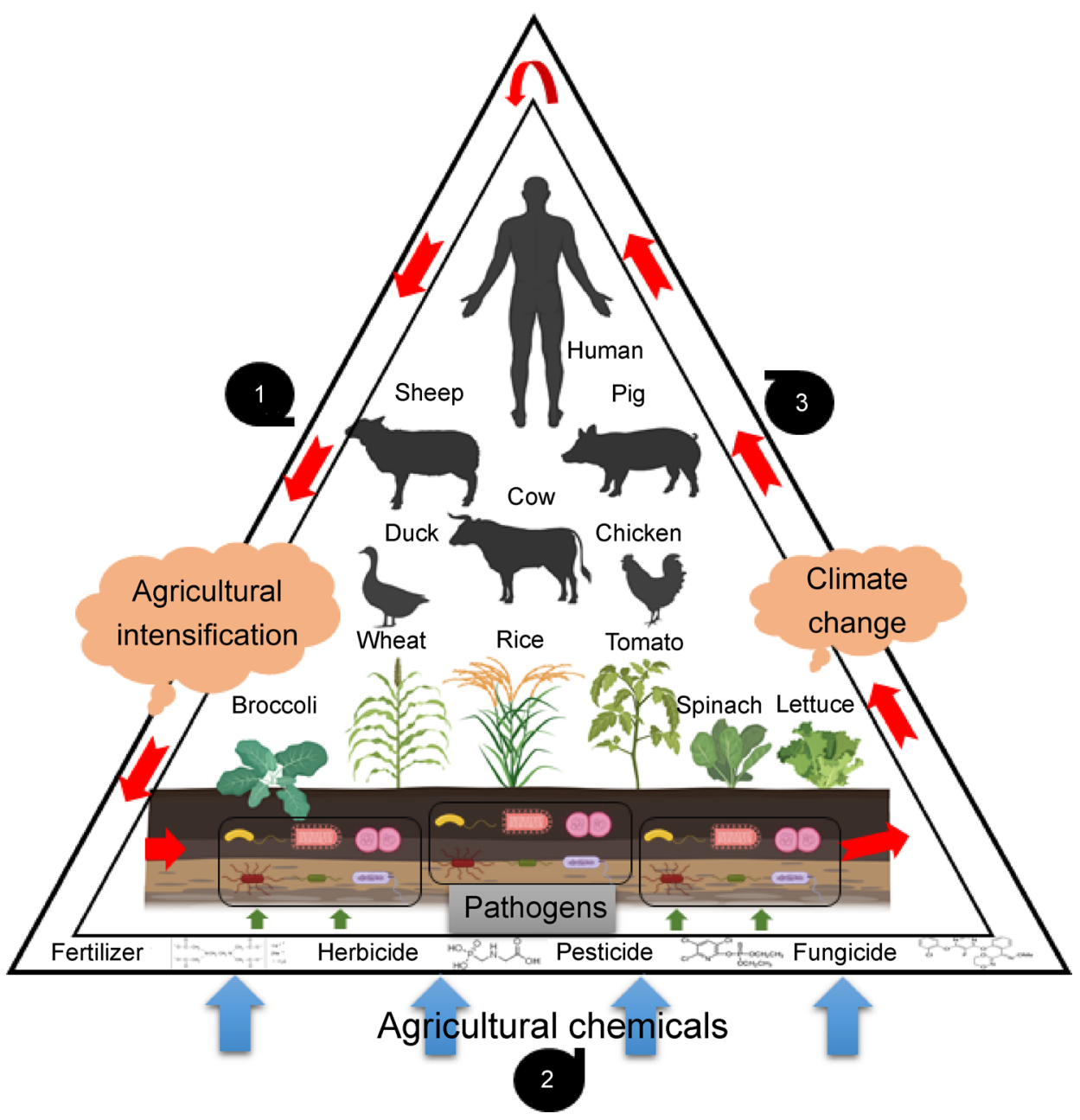

Fig. 1 Flow of soil pathogenic bacteria caused by agrochemicals.

more than one million distinct bacterial genomes (Gans et al., 2005 ), but only approximately up to $5 \%$ of these bacteria have been cultured by current methodologies. Soil is therefore considered as a black box in the field of microbiology, and the diversity of soil microbiomes may be highly underestimated. Soil microorganisms can be divided into those beneficial to plants, pathogenic to plants, and pathogenic to humans (Mendes et al., 2013), and the others interaction with soil microorganisms.

Invasions by plant pathogens have substantially damaged plant communities and have reduced agricultural yields. Pathogens spread predominantly among neighboring plants, and the spatial distribution and density of host populations will determine the threshold of soil-borne epidemics. A crop rotation system is a useful practice for managing diseases (Mundt, 2002), and disease-suppressive soils can be induced in the field to prevent disease outbreaks during the continuous cultivation of a susceptible host plant (Mendes et al., 2011; Raaijmakers and Mazzola, 2016; Kwak et al., 2018).

Some opportunistic soil-dwelling pathogens are associated to human health, and the rhizosphere is a natural reservoir for them. These human pathogenic microorganisms from the soil can use various plant species as hosts (Berg et al., 2005), and their impact on human health has increased dramatically over the last two decades (Teplitski et al., 2009), but due to the lack of adequate animal research models, little is known about their virulence factors relative to their clinical counterparts (Berg et al., 2005). The occurrence of human pathogenic bacteria in soil may be due to the high contents of nutrients, protection from UV radiation, and the availability of water films for dispersal and prevention of desiccation (Berg et al., 2005; Tyler and Triplett, 2008). We can also not exclude the possibility that wild animals carrying various human pathogenic bacteria transferred them to agricultural fields or that organic fertilizers used in agricultural production originally contained the pathogenic bacteria (Hofmann et al., 2014). Many human pathogenic bacteria can be highly competitive for nutrients and can produce various antimicrobial metabolites that allow them to colonize and proliferate on plant surfaces and in the soil (Mendes et al., 2013). Plants also provide an easy access point for the invasion and colonization of human pathogenic bacteria during large-scale agricultural production (Teplitski et al., 2009; Aundy and Munder, 2012), which may be transferred to humans through the food chain. 
Table 1 Soil pathogensand the associated human disease.

\begin{tabular}{ll}
\hline Disease & Soil pathogens \\
\hline Plague (Bubonic \& Pneumonic) & Yersinia pestis \\
Melioidosis & Burkholderia pseudomallei \\
Anthrax & Bacillus anthracis \\
Tetanus & Clostridium tetani \\
Botulism & Clostridium botulinum \\
Listeriosis (gastrointestinal; meningitis) & Listeria monocytogenes \\
Tularemia & Francisella tularensis \\
Leprosy & Mycobacterium leprae \\
Shigellosis & Shigella spp. \\
Gastrointestinal disease & Salmonella enterica \\
Gastrointestinal disease & Campylobacter spp. \\
Gastrointestinal disease & Escherichia coli (esp. HO157:H7) \\
Legionnaires' disease & Legionella spp. \\
Coccidioidomycosis & Coccidioides spp. \\
Blastomycosis & Blastomyces dermatitdis \\
Histoplasmosis & Histoplasma capsulatum \\
Sporotrichosis & Sporothrix schenckii \\
Meningitis & Exserohilum rostratum \\
Multiple & Viruses (unknown, emerging) \\
\hline
\end{tabular}

\section{Changing soil health}

Microbes play a major role in ecosystem functioning and contribute to the health and fitness of higher organisms. The abundance and diversity of the soil microbiome are the key factor determining the status of soil health, mainly because the beneficial and pathogenic effects depend on the abundance of related microorganisms (Maurhofer et al., 1992). The physical properties of the soil, including the shape and size of soil aggregates and other parameters such as soil moisture, $\mathrm{pH}$, and temperature, influence these abundances. Environments, however, are changing around the globe at an unprecedented rate. Habitat is being degraded and homogenized, and nutrient runoff from fertilizers and pesticide use are problematic in industrial-scale agricultural settings (Foley et al., 2005; Stocker et al., 2013). Under these circumstances, changes in soil microbial diversity and structure directly affect the persistence of human pathogens in the soil, such as Salmonella is more durable in high-temperature sterilized soil (Schierstaedt et al., 2020). Furthermore, the global mean surface temperature is increasing, which may contribute to prolonged droughts and flooding, and increased the probability of exposure to frozen pathogens. One example is that the endospores of Siberian anthrax have been shown to survive in the permafrost for about 105 years, and the anthrax can be transmitted to humans through reindeer (Boris et al., 2012). All these factors severely threaten the biodiversity of soil microbial communities. Virtually all ecosystems on Earth Agricultural intensification with low crop diversity especially affects network complexity and the abundance of keystone taxa in soil- and plant-associated communities, with subsequent impacts on ecosystem services (Banerjee et al., 2019). These changes in microorganisms can undoubtedly affect host nutrition, behavior, physiology, devel- opment, and survival in various ways (Lynch and Hsiao, 2019), and caused an explosion of soil human pathogens between the ecosystems and human.

\section{Controlling pathogens using soil management}

Feeding a growing world population, mitigating climate change, and ensuring the sustainability of cultivated land are important issues in agriculture. The potential for such settings to contribute to epidemics and pandemics of pathogens deserves further attention. Scientists are continually increasing yields and creating resistant crops, but monocultures of such crops decrease microbial diversity and may facilitate the buildup of soil-borne pathogens. Solving these predicaments should entail: 1) enhancing crop diversity, rotating crops, and increasing plant spacing and the use of crop mixtures (Leclerc et al., 2013), and 2) introducing specific microbial associations in combination with microbiome-optimized plant genotypes, which can assist hosts to take up nutrients and enhance stress tolerance by stimulating their immune systems, with reduced inputs of chemical pesticides and fertilizers. Microbial rescue using probiotic supplements or microbiome engineering is a promising approach to maintain persistence in a changing world or to create desired functions (e.g., host immunity, nutrient supply and energy circulation) (Lawson et al., 2019; Mueller et al., 2019). The long road ahead, however, will require further research for understanding the interactions among microbiota and plant hosts and developing effective strategies to manipulate microbiota for preventing the emergence of infectious diseases, because this field of science is still young. Management strategies are urgently needed to 
reduce the pressing problem of environmentally acquired infections from pathogenic soil microorganisms. These issues are important lessons from the current COVID-19 pandemic. Rapidly identifying potential human pathogens in soil, predicting their routes of transmission from soil to humans, and developing effective therapeutic agents will particularly be necessary.

\section{Acknowledgments}

This work was financially supported by the National Natural Science Foundation of China (41907210, 21777144, 21976161).

\section{References}

Aundy, K., Munder, A., Aravind R., Eapen, S.J., Tümmler, B., Raaijmakers, J.M., 2012. Friend or foe: Genetic and functional characterization of plant endophytic Pseudomonas aeruginosa. Environmental Microbiology 15, 764-779.

Banerjee, S., Walder, F., Büchi, L., Meyer, M., Held, A., Gattinger, A., Keller, T., Charles, R., Van der Heijden, M., 2019. Agricultural intensification reduces microbial network complexity and the abundance of keystone taxa in roots. ISME Journal 13, 1722-1736.

Bassler, B., 1999. How bacteria talk to each other: regulation of gene expression by quorum sensing. Current Opinion in Microbiology 2, 582-587.

Bellas, C., Anesio, A., Barker, G., 2015. Analysis of virus genomes from glacial environments reveals novel virus groups with unusual host interactions. Frontiers in Microbiology 6, 656.

Berg, G., Eberl, L., Hartmann, A., 2005. The rhizosphere as a reservoir for opportunistic human pathogenic bacteria. Environmental Microbiology 7, 1673-1685.

Boris, R., Nikolai, T., Alan, J.P., 2012. Climate change and zoonotic infections in the Russian Arctic. International Journal of Circumpolar Health 71, 18792.

Danovaro, R., Dell'Anno, A., Corinaldesi, C., Magagnini, M., Noble, R., Tamburini, C., Weinbauer, M., 2008. Major viral impact on the functioning of benthic deep-sea ecosystems. Nature 454, 1084 1087.

Foley, J., Defries, R., Asner, G., Barford, C., Bonan, G., Carpenter, S., Chapin lii, F.S., Coe, M., Daily, G., Gibbs, H., Helkowski, J., Holloway, T., Howard, E., Kucharik, C., Monfreda, C., Patz, J., Prentice, I., Ramankutty, N., Snyder, P., 2005. Global consequences of land use. Science 309, 570-574.

Foley, J., Ramankutty, N., Brauman, K., Cassidy, E., Gerber, J., Johnston, M., Mueller, N., O'Connell, C., Ray, D., West, P., Balzer, C., Bennett, E., Carpenter, S., Hill, J., Monfreda, C., Polasky, S., Rockström, J., Sheehan, J., Siebert, S., Zaks, D., 2011. Solutions for a cultivated planet. Nature 478, 337-342.

Frenken, T., Brussaard, C., Velthuis, M., Aben, R., Kazanjian, G., Hilt, S., Kosten, S., Peeters, E., de Senerpont Domis, L., Stephan, S., Donk, E., Van de Waal, D., 2020. Warming advances virus population dynamics in a temperate freshwater plankton community. Limnology and Oceanography Letters 5, 295-304.

Gans, J., Wolinsky, M., Dunbar, J., 2005. Computational improvements reveal great bacterial diversity and high metal toxicity in soil. Science 309, 1387-1390.

Gattuso, J.-P., Magnan, A.; Billé, R., Cheung, W., Howes, E. L., Joos, F., Allemand, D., Bopp, L., Cooley, S., Eakin, C. M., HoeghGuldberg, O., Kelly, R., Pörtner, H.-O., Rogers, A., Baxter, J., Laffoley, D., Osborn, D., Rankovic, A., Rochette, J., Turley, C., 2015. Contrasting futures for ocean and society from different anthropogenic $\mathrm{CO} 2$ emissions scenarios. Science 349, 1-10.

Hofmann, A., Fischer, D., Hartmann, A., Schmid, M., 2014. Colonization of plants by human pathogenic bacteria in the course of organic vegetable production. Frontiers in Microbiology 5, 191.

Kwak, M.J., Kong, H.G., Choi, K., Kwon, S.K., Song, J.Y., Lee, J., Lee, P.A., Choi, S.Y., Seo, M., Lee, H.J., Jung, E.J., Park, H., Roy, N., Kim, H., Lee, M.M., Rubin, E.M., Lee, S.W., Kim, J.F., 2018. Rhizosphere microbiome structure alters to enable wilt resistance in tomato. Nature Biotechnology 36, 1100-1109.

Labbé, M., Girard, C., Vincent, W., Culley, A., 2020. Extreme viral partitioning in a marine-derived high arctic lake. MSphere 5, e00334-e20.

Lawson, C., Harcombe, W., Hatzenpichler, R., Lindemann, S., Löffler, F., O’Malley, M., Martín, H., Pfleger, B., Raskin, L., Venturelli, O., Weissbrodt, D., Noguera, D., McMahon, K., 2019. Common principles and best practices for engineering microbiomes. Nature Reviews. Microbiology 17, 1-17.

Leclerc, M., Doré, T., Gilligan, C., Lucas, P., Filipe, J., 2013. Host growth can cause invasive spread of crops by soilborne pathogens. PLoS One 8, e63003.

Locatelli, A., Spor, A., Jolivet, C., Piveteau, P., Hartmann, A., 2013. Biotic and abiotic soil properties influence survival of listeria monocytogenes in soil. PLoS One 8, e75969.

Lynch, J., Hsiao, E., 2019. Microbiomes as sources of emergent host phenotypes. Science 365, 1405-1409.

Maurhofer, M., Keel, C., Schnider, U., Voisard, C., Haas, D., Défago, G., 1992. Influence of enhanced antibiotic production in pseudomonas fluorescens strain $\mathrm{CHAO}$ on its disease suppressive capacity. Phytopathology 82, 190-195.

Mendes, R., Garbeva, P., Raaijmakers, J., 2013. The rhizosphere microbiome: Significance of plant beneficial, plant pathogenic, and human pathogenic microorganisms. FEMS Microbiology Reviews 37, 34-63.

Mendes, R., Kruijt, M., Bruijn, I., Dekkers, E., Voort, M., Schneider, J., Piceno, Y., DeSantis, T., Andersen, G., Bakker, P., Raaijmakers, J., 2011. Deciphering the rhizosphere microbiome for diseasesuppressive bacteria. Science 332, 1097-1100.

Mueller, E., Wisnoski, N., Peralta, A., Lennon, J., 2019. Microbial rescue effects: How microbiomes can save hosts from extinction. Functional Ecology 00, 1-10.

Mundt, C., 2002. Use of multiline cultivars and cultivar mixtures for disease management. Annual Review of Phytopathology 40, 381410.

Raaijmakers, J., Mazzola, M., 2016. Soil immune responses. Science 352, 1392-1393.

Schierstaedt, J., Jechalke, S., Nesme, J., Neuhaus, K., Sørensen, S., Grosch, R., Smalla, K., Schikora, A., 2020. Salmonella persistence in soil depends on reciprocal interactions with indigenous microorganisms. Environmental Microbiology 22, 2639-2652. 
Steffan, J.J., Derby, J.A., Brevik, E.C., 2020. Soil pathogens that may potentially cause pandemics, including SARS coronaviruses. Current Opinion in Environmental Science \& Health. Doi.org/ 10.1016/j.coesh.2020.08.005.

Stocker, T., Qin, D., Plattner, G.K., Tignor, M., Allen, S.K., Boschung, J., Nauels, A., Xia, Y., Bex, V., Midgley, P.M., 2013. Climate Change 2013: The Physical Science Basis. Cambridge University Press, Cambridge 33-115.

Teplitski, M., Barak, J., Schneider, K., 2009. Human enteric pathogens in produce: Un-answered ecological questions with direct implications for food safety. Current Opinion in Biotechnology 20, 166-171.

Tyler, H., Triplett, E., 2008. Plants as a habitat for beneficial and/or human pathogenic bacteria. Annual Review of Phytopathology 46, 53-73.

Vannier, N., Agler, M., Hacquard, S., 2019. Microbiota-mediated disease resistance in plants. PLoS Pathogens 15, e1007740.

Williamson, K., Fuhrmann, J., Wommack, K.E., Radosevich, M., 2017.
Viruses in soil ecosystems: an unknown quantity within an unexplored territory. Annual Review of Virology 4, 201-219.

Wu, S.P., 2017. Prevention and control of emerging infectious diseases, an eternal topic of mankind. Electronic Journal of Emerging Infectious Diseases 2, 1-4.

Zhang, G.L., Gao, Z.L., 2018. Emerging infectious diseases and the strategy of prevention and control. Chinese Journal of Viral Diseases 8, 252-256.

Zhong, Z., Rapp, J., Wainaina, J., Solonenko, N., Maughan, H., Carpenter, S., Cooper, Z., Jang, H.B., Bolduc, B., Deming, J., Sullivan, M., 2020. Viral ecogenomics of arctic cryopeg brine and sea ice. mSystems 5, e00246-e20.

Zhu, Y.G., Gillings, M., Penuelas, J., 2020. Integrating biomedical, ecological, and sustainability sciences to manage emerging infectious diseases. One Earth 3, 23-26.

Zhu, Y.G., Gillings, M., Simonet, P., Stekel, D., Banwart, S., Penuelas, J., 2017. Microbial mass movements. Science 357, 1099-1100. 